\title{
Gambaran pengetahuan, sikap dan perilaku tentang manajemen diet pada pasien hipertensi di Garut, Indonesia
}

\author{
Via Komalasari, Iwan Shalahuddin*, Hasniatisari Harun
}

Fakultas Keperawatan Universitas Padjadjaran Bandung Jawa Barat, Indonesia

*Email: shalahuddin@unpad.ac.id

\section{Abstract \\ Hypertension knowledge, attitudes, and behavior related to diet management among patient with hypertension in Garut-Indonesia}

Background: Hypertension is a non-communicable disease in which cases are still many in Indonesia. The knowledge, attitude and patient behavior with proper diet management would like to recover. Knowledge is something that can underlie or encourage someone to take action or behavior. The recommended hypertension diet for people with hypertension is the consumption of food that is low in salt, low in fat, increase fibre, increase potassium intake, do not consume cigarette, coffee and alcohol, increase consumption of vegetable and fruit.

Purpose: To determine description of Hypertension knowledge, attitudes, and behavior related to diet management among patient with hypertension in Garut-Indonesia

Method: A quantitative approach with the population were patient with hypertension in Guntur Health Center, the samples were of 159 respondent using accidental sampling techniques. The instrument used as a questionnaire which includes knowledge, attitude and behaviour. Data analysis used univariate analysis.

Results: Showed that most respondents had a good level of knowledge of $152(95,6 \%)$ respondent, 159 people $(100 \%)$ had a supportive attitude, and of $159(100 \%)$ respondent had a positive behavior. Reported that there were some behaviours need to change or preserve as local wisdom such as reducing the consumption of full cream milk, biscuit and egg yolk and maintaining consumption of fruit, vegetable and food that contain low fat.

Conclusion: Base on the result expected to use as a reference and learning both in the provision of health education or other nursing care for the knowledge, attitude and behaviour of hypertension sufferers about dietary.

Keywords: Hypertension; Knowledge; Attitudes; Behavior; Diet management; Patient.

Pendahuluan: Diet hipertensi merupakan salah satu penatalaksanaan hipertensi yang mudah untuk diubah. Diet hipertensi bisa meningkatkan status kesehatan seseorang, status kesehatan seseorang bisa dipengaruhi oleh perilaku. Faktor yang yang erat kaitanya dengan perilaku adalah pengetahuan dan sikap. Pengetahuan yang baik dan sikap yang mendukung akan membantu terlaksananya penatalaksanaan hipertensi dengan benar.

Tujuan: Untuk mengetahui gambaran pengetahuan, sikap dan perilaku penderita hipertensi tentang manajemen diet.

Metode: Penelitian deskriptif kuantitatif, populasinya semua pasien yang menderita hipertensi di wilayah Garut dengan jumlah sampelnya sebanyak 159 responden dengan teknik pengambilan sampel accidental sampling. Instrumen yang digunakan dalam bentuk kuesioner, yang meliputi: pengetahuan, sikap dan perilaku. Analisis data menggunakan analisis univariat

Hasil: Menunjukan bahwa sebagian besar responden memiliki tingkat pengetahuan baik yaitu 152 orang $(95,6 \%)$, sebanyak $159(100 \%)$ responden memiliki sikap yang mendukung dan $159(100 \%)$ responden memiliki perilaku yang positif.

Simpulan: Ada beberapa perilaku yang harus ditingkatkan seperti mengurangi konsumsi susu full cream, biskuit dan kuning telur serta mempertahankan perilaku yang sudah baik seperti konsumsi buah, sayur dan makanan yang mengandung rendah lemak.

Kata Kunci : Gambaran; Pengetahuan; Perilaku; Sikap; Manajemen diet; Pasien; Hipertensi. 
Gambaran pengetahuan, sikap dan perilaku tentang manajemen diet pada pasien hipertensi di Garut, Indonesia

\section{PENDAHULUAN}

Menurut American College of Cardiologi/American Heart Association (ACC/AHA) tahun 2018, hipertensi merupakan peningkatan tekanan darah sistolik $\geq 130 \mathrm{mmHg}$, dan diastolik $\geq 80 \mathrm{mmHg}$. Hipertensi kini menjadi penyakit tertinggi ketiga penyebab kematian di Indonesia setelah TBC dan Stroke (Wandi \& Amin, 2017). Tanda dan gejala dari hipertensi yaitu seperti mengeluh pusing, lemas, gelisah, mual, muntah (Huda \& Kusuma, 2015). Menurut Yuli pada tahun 2014, hipertensi dapat disebabkan oleh faktor keturunan, umur, jenis kelamin, dan gaya hidup. Gaya hidup yang sering menyebabkan hipertensi yaitu seperti konsumsi garam yang tinggi, obesitas, stres, merokok, minum alkohol, minum obatobatan.

Menurut World Health Organization [WHO] tahun 2018, 1,13 miliar orang menderita Hipertensi. Sedangkan menurut Kemenkes tahun 2016 terdapat 63.309.620 kasus di Indonesia. Menurut data dari Riskesdas (2018), Prevalensi hipertensi di Jawa Barat naik dari yang awalnya $25,8 \%$ pada tahun 2013 , menjadi $34,1 \%$ pada tahun 2018.

Menurut Profil Kesehatan Provinsi Jawa Barat tahun 2016, penyakit hipertensi di Kabupaten Garut menempati peringkat ke-11 di Jawa Barat dengan 3,24\%. Menurut data Dinas Kesehatan Kabupaten Garut (2018) terdapat 82638 kasus hipertensi di Garut yang tersebar di 67 wilayah kerja Puskesmas di Kabupaten Garut. Puskesmas Guntur menempati peringkat ke 1 dengan 4239 kasus, Puskesmas Guntur terletak di dekat pusat oleh-oleh khas kota Garut yang mungkin dapat menyebabkan adanya perubahan gaya hidup yang dibawa oleh pendatang pada masyarakat di wilayah kerja Puskesmas Guntur seperti terbiasa dengan makanan junk food / fast food, dengan adanya perubahan gaya hidup tersebut dapat menjadikan Puskesmas Guntur sebagai Puskesmas tertinggi dengan angka kejadian hipertensi dibandingkan Puskesmas lainnya.

Data Riskesdas tahun 2013 menunjukan bahwa ada penderita hipertensi di Indonesia sebanyak 25,8\% namun dalam pengontrolan hipertensi belum sepenuhnya dapat dilakukan meskipun sudah ada obat-obatan yang efektif (Kiha, Palimbong, \& Kurniasari, 2018). Pola makan merupakan salah satu faktor risiko yang mudah untuk diubah (Abdurrachim, Libri, Gz, \& Mariana, 2015).
Pola makan merupakan salah satu perilaku manusia yang dilakukan setiap hari dalam memenuhi kebutuhannya (Anisah \& Soleha, 2018). Pola makan dengan mengkonsumsi makanan yang dianjurkan dapat mengendalikan tekanan darah karena menjadi salah satu penatalaksanaan bagi penderita hipertensi. Beberapa makanan yang disarankan kepada penderita hipertensi yaitu dengan mengurangi konsumsi makanan yang mengandung garam dan lemak, mengurangi asupan garam, mengurangi alkohol, perbanyak makan sayur dan buah-buahan, hindari makanan seperti jeroan, otak, makanan bersantan yang kental, kulit ayam dan perbanyak minum air putih. Hasil dari penelitian Anisah dan Soleha menyatakan bahwa sebagian besar pasien di ruang rawat inap di IRNA F RSUD Syarifah Ambami Rato Ebu Kabupaten Bangkalan Madura memiliki pola makan yang tidak sesuai dengan diet hipertensi (Anisah \& Soleha, 2018).

Pola makan yang baik dapat meningkatkan status kesehatan pasien hipertensi. Menurut H.L.Blum status kesehatan seseorang salah satunya dipengaruhi oleh perilaku. Perilaku seseorang dapat mempengaruhi kepada penatalaksanaan hipertensi (Zaini, Ratnawati, \& Ririanty, 2015)

Perilaku adalah suatu tindakan yang dapat diamati dan mempunyai frekuensi spesifik, durasi dan tujuan baik disadari maupun tidak. Perilaku adalah kumpulan berbagai faktor yang saling berinteraksi (Wawan \& Dewi, 2016). Sikap dan pengetahuan seseorang menjadi alasan keberhasilan terlaksananya diet hipertensi (Runtukahu, Rompas, \& Pondaag, 2015). Sikap menurut Anggreani (2019) adalah sebuah konsep yang paling penting dalam kehidupan sosial yang berhubungan erat dengan pembentukan karakter dalam individu maupun antar kelompok. Sedangkan pengetahuan tentang suatu penyakit dan berbagai kebiasaan hidup dapat digunakan untuk mencegah terjadinya penyakit atau terjadinya kekambuhan (Abdurrachim et al., 2015). Pengetahuan dapat sangat mempengaruhi hipertensi dalam memanajemen hipertensi (Firmawati, 2014). Pengetahuan adalah hasil dari proses penginderaan manusia, atau seseorang yang tahu terhadap objek melalui indera yang sudah dilaluinya seperti mata, hidung, telinga (Wawan \& Dewi, 2016).

Perawat memiliki peran mengubah perilaku penderita hipertensi dalam menghindari suatu 
Gambaran pengetahuan, sikap dan perilaku tentang manajemen diet pada pasien hipertensi di Garut, Indonesia

penyakit atau memperkecil resiko dari sakit yang dideritanya. Peran perawat yaitu sebagai educator yang memberikan informasi hipertensi dalam pengetahuan pasien dan dapat membentuk sikap yang positif agar pasien dapat melakukan perawatan hipertensi secara mandiri sehingga dapat mencegah komplikasi (Damayantie, Heryani, \& Muazir, 2018). Hipertensi bisa menyebabkan komplikasi seperti stroke, infark miokard, gagal ginjal, ensefalopati, dan kejang (Syamsudin, 2011).

Berdasarkan hasil observasi, peneliti mengambil di Puskesmas Guntur selain dikarenakan Puskesmas Guntur berada di daerah perkotaan, pasien Hipertensi di Puskesmas Guntur juga masih sangat tinggi, itu bisa disebabkan karena adanya faktor budaya di lingkungan Puskesmas Guntur yang dapat mempengaruhi pengetahuan, sikap dan perilaku pasien hipertensi tersebut. Berdasarkan data dari perawat Puskesmas Guntur, dalam kegiatan Prolanis Puskesmas Guntur sudah memberikan penyuluhan terkait diet hipertensi seperti makanan apa saja yang dianjurkan dan makanan apa saja yang tidak dianjurkan. Tetapi saat dilakukan studi pendahuluan, 3 dari 9 orang masih mengkonsumsi makanan dengan garam berlebih dan 6 dari 9 orang masih mengkonsumsi gorengan dan biskuit.

\section{METODE PENELITIAN}

Penelitian deskriptif kuantitatif dan populasinya pasien hipertensi yang berobat ke puskesmas Guntur Garut yaitu 265 pasien dengan menggunakan rumus Slovin didapatkan hasil 159 pasien untuk dijadikan responden, dengan teknik pengambilan sampel yaitu Accidental Sampling.

Kuesioner pengetahuan yaitu diukur dengan cara menjawab 15 pertanyaan. Jika pada pertanyaan $1,2,5,6,9,10,11$ 12, 14, 15 dijawab oleh responden "YA" maka akan diberi nilai 1. Kuesioner pengetahuan ini meliputi pengertian, tujuan diet hipertensi, makanan apa saja yang dianjurkan dan makanan apa saja yang dihindari. Jika pada pertanyaan $3,4,7,8$, dan 13 dijawab "TIDAK" oleh responden maka akan diberi nilai 1, sehingga skor total 15. Hasil akhir dikatakan $1=$ Baik jika hasil $>$ median, $2=$ Kurang jika hasil $<$ median, dengan median $=8$.

Kuesioner sikap yaitu diukur dengan menjawab 10 pertanyaan, yang terdiri dari pernyataan positif dan negatif. Jika pertanyaan positif no 1, 2, 3, 5, 6,
8, 9, 10 jika responden menjawab SS akan diberi skor 4, jika S diberi skor 3, jika KS diberi skor 2, dan jika TS diberi skor 1 . Didalam kuesioner ini meliputi pernyataan-pernyataan keseharian bagi pasien hipertensi, seperti sikap saat responden merasa pusing dan sikap bagaimana pola makan sehari-hari responden. Jika pada pertanyaan negatif no 4 dan 7 jika responden menjawab TS akan diberi skor 4, jika KS diberi skor 3, jika S diberi skor 2, jika SS diberi skor 1. Sehingga total skor adalah 40. Hasil akhir dikatakan $1=$ Mendukung jika nilai > Median, 2 = Tidak Mendukung jika nilai $<$ Median, Dengan Median $=$ 20.

Kuesioner perilaku yaitu diukur dengan cara menjawab kuesioner sebanyak 20 pertanyaan. Jika pada pertanyaan positif no 2, 4, 5, 6, 8, 9, 11, 15 responden menjawab Selalu diberi skor 4 , jika Sering diberi skor 3, jika Jarang diberi skor 2, jika Tidak Pernah diberi skor 1. Didalam kuesioner ini berisi pernyataan tentang tindakan atau perilaku yang dilakukan seseorang setiap harinya meliputi, apakah responden memakan sayur, buah, daging, makanan yang mengandung garam atau yang asin, dan makanan lainnya baik yang dianjurkan untuk pasien hipertensi atau yang tidak dianjurkan untuk pasien hipertensi. Jika pada pertanyaan no 1, 3, 7, 10, 12, 13, 14 responden menjawab Tidak Pernah diberi skor 4, jika Jarang diberi skor 3, jika Sering diberi skor 2, jika Selalu diberi skor 1. Sehingga total skor adalah 60 . Hasil akhir dikatakan 1 = Positif jika nilai $>$ Median, 2 = Negatif jika nilai $<$ Median, Dengan Median $=30$.

Uji validitas instrumen dilakukan dengan hasil nilai terkecil 0,568 dan nilai terbesar 0,883 , uji reliabilitas didapat nilai 0,963 . Sedangkan untuk instrumen sikap didapatkan hasil 0,890, sedangkan untuk instrumen perilaku didapatkan hasil 0,611.Proses pengambilan data dilakukan dengan menyebar kuesioner kepada responden dengan mengikuti jadwal posbindu yang berada di wilayah kerja puskesmas Guntur dengan berada pada 3 kelurahan. Kuesioner yang digunakan merupakan kuesioner dari peneliti sebelumnya (Nuridayanti, 2016; Maulida, 2016). Pengelolaan dan analisis data menggunakan tabel distribusi dan frekuensi.

Penelitian ini sudah memiliki kelayakan uji dari Komite Etik Penelitian Universitas Padjadjaran dengan nomor etik 1533/UN6.KEP/EC/201. 
Gambaran pengetahuan, sikap dan perilaku tentang manajemen diet pada pasien hipertensi di Garut, Indonesia

HASIL

Tabel 1. Distribusi Frekuensi Karakteristik Responden ( $N=159)$

\begin{tabular}{|c|c|c|c|c|}
\hline Karakteristik & & Frekuensi (f) & Presentasi (\%) & $(\mathrm{M} \pm \mathrm{SD})$ \\
\hline Usia (Tahun) (Rentang: 24-85) & & 159 & 100 & $58.26 \pm 12.41$ \\
\hline $\begin{array}{l}\text { Lama Menderita (Tahun) } \\
\text { (Rentang: 1-11) }\end{array}$ & & 159 & 100 & $3.33 \pm 2.604$ \\
\hline Jenis Kelamin & $\begin{array}{l}\text { Laki-laki } \\
\text { Perempuan }\end{array}$ & $\begin{array}{c}24 \\
135\end{array}$ & $\begin{array}{l}15.2 \\
84.9\end{array}$ & \\
\hline Pekerjaan & $\begin{array}{l}\text { PNS } \\
\text { Wiraswasta } \\
\text { Buruh } \\
\text { Tidak Bekerja }\end{array}$ & $\begin{array}{c}1 \\
2 \\
13 \\
143\end{array}$ & $\begin{array}{c}0.6 \\
1.3 \\
8.2 \\
89.9\end{array}$ & \\
\hline Status Perkawinan & $\begin{array}{l}\text { Belum Menikah } \\
\text { Menikah } \\
\text { Bercerai } \\
\text { Janda/Duda }\end{array}$ & $\begin{array}{c}1 \\
110 \\
4 \\
44\end{array}$ & $\begin{array}{c}0.6 \\
69.2 \\
2.5 \\
27.7\end{array}$ & \\
\hline Pendidikan Terakhir & $\begin{array}{l}\text { SD } \\
\text { SMP } \\
\text { SMA } \\
\text { Perguruan Tinggi }\end{array}$ & $\begin{array}{l}80 \\
47 \\
29 \\
3\end{array}$ & $\begin{array}{c}50.3 \\
28.6 \\
18.2 \\
1.9\end{array}$ & \\
\hline $\begin{array}{l}\text { Data Kesehatan Penderita } \\
\text { Hipertensi }\end{array}$ & & & & \\
\hline IMT & $\begin{array}{l}\text { Kurus } \\
\text { Normal } \\
\text { Gemuk }\end{array}$ & $\begin{array}{c}4 \\
75 \\
80\end{array}$ & $\begin{array}{c}2.5 \\
47.2 \\
50.3\end{array}$ & \\
\hline Tekanan Darah & $\begin{array}{l}\text { Derajat } 1 \\
\text { Derajat } 2 \\
\text { Derajat } 3\end{array}$ & $\begin{array}{l}103 \\
45 \\
11\end{array}$ & $\begin{array}{l}64.8 \\
28.3 \\
76.9\end{array}$ & \\
\hline Konsumsi Obat & $\begin{array}{l}\text { Ya } \\
\text { Tidak }\end{array}$ & $\begin{array}{l}110 \\
49\end{array}$ & $\begin{array}{l}69.2 \\
30.8\end{array}$ & \\
\hline Pengetahuan & $\begin{array}{l}\text { Baik } \\
\text { Buruk }\end{array}$ & $\begin{array}{c}152 \\
7\end{array}$ & $\begin{array}{c}95.6 \\
4.4\end{array}$ & \\
\hline Sikap & $\begin{array}{l}\text { Mendukung } \\
\text { Tidak Mendukung }\end{array}$ & $\begin{array}{c}159 \\
0\end{array}$ & $\begin{array}{c}100 \\
0\end{array}$ & \\
\hline Perilaku & $\begin{array}{l}\text { Positif } \\
\text { Negatif }\end{array}$ & $\begin{array}{c}159 \\
0\end{array}$ & $\begin{array}{c}100 \\
0\end{array}$ & \\
\hline
\end{tabular}

Berdasarkan tabel 1, diperoleh data karakteristik demografi bahwa responden berada pada usia minimum 24 tahun, maximum 85 tahun

dengan mean 58.26 dan standar deviasi 12.407. Untuk lamanya menderita yang dialami minimum selama 1 tahun, maximum 11 tahun 
Gambaran pengetahuan, sikap dan perilaku tentang manajemen diet pada pasien hipertensi di Garut, Indonesia

dengan mean 3.33 dan standar deviasi 2.604 . Dengan 135 orang (84.9) berjenis kelamin perempuan, dengan status perkawinan sebanyak 110 orang $(69.2 \%)$ sudah menikah, dengan tingkat pendidikan 80 orang (50.3) berpendidikan Sekolah Dasar (SD).

Berdasarkan data kesehatan penderita hipertensi yaitu dengan IMT gemuk sebanyak 80 orang $(50.3 \%)$, sebagian besar responden memiliki hipertensi derajat 1 sebanyak 103 orang (64.8\%), dengan mengkonsumsi obat sebanyak 110 orang (69.2).

Berdasarkan data pengetahuan pada penderita hipertensi bahwa hampir seluruh responden penderita hipertensi memiliki tingkat pengetahuan baik dengan hasil 152 orang (95.6\%), dan responden penderita hipertensi dengan tingkat pengetahuan buruk sebanyak 7 orang (4.4\%), pada sikap penderita hipertensi bahwa seluruh responden memiliki sikap yang mendukung yaitu sebanyak 159 responden $(100 \%)$ dan perilaku pada penderita hipertensi bahwa seluruh responden sebanyak 159 orang (100\%) memiliki perilaku yang positif terhadap diet hipertensi.

\section{PEMBAHASAN}

\section{Pengetahuan}

Setelah dilakukan penelitian mengenai gambaran pengetahuan penderita hipertensi tentang pengaturan diet makanan di Puskesmas Guntur Garut lebih banyak responden yang memiliki tingkat pengetahuan baik sebanyak 152 orang $(95,6 \%)$, hasil tersebut sejalan dengan hasil penelitian Abdurrachim et al., (2015) bahwa terdapat $42.6 \%$ memiliki tingkat pengetahuan yang baik. Menurut Notoatmodjo (dalam Wawan \& Dewi 2016), pengetahuan dipengaruhi oleh faktor internal salah satunya adalah umur. Umur responden paling banyak adalah umur 56-65 tahun yaitu 51 orang $(32,1 \%)$.

Semakin bertambahnya umur akan semakin banyak informasi yang didapat misalnya dari petugas kesehatan, semakin bertambahnya juga pengalaman yang dijumpai dan dikerjakan Dewifianita (2017). Pengetahuan merupakan perkumpulan dari sebuah pengalaman seseorang (Anita, 2014). Dalam penelitian Hernawan \& Arifah (2012) dijelaskan bahwa jika seseorang memiliki tingkat pengetahuan yang baik dapat dipengaruhi oleh tingkat pendidikan yang baik, tetapi pengetahuan tersebut dapat ditemukan dari sumber yang lain seperti radio, koran, telepon seluler, televisi, majalah, atau tetangga, bukan hanya dari pendidikan yang didapat secara formal saja. Hasil ini tidak sejalan dengan hasil penelitian Anisa \& Bahri (2014) yang mengatakan bahwa pengetahuan seseorang dapat dipengaruhi oleh tingkat pendidikan seseorang, salah satunya adalah pengetahuan dalam menetapkan perilaku hidup sehat. Selain dipengaruhi oleh pendidikan, pengetahuan juga dapat dipengaruhi oleh lama menderita penyakit, seseorang yang sudah lama menderita suatu penyakit, akan terbiasa terhadap penyakit tersebut sehingga akan memiliki pengetahuan yang baik (Proboningsih et al., 2019).

Dari hasil penelitian ini, sebagian besar responden sudah mengetahui makanan apa saja yang dianjurkan seperti makanan yang mengandung magnesium, protein, dan tinggi serat. Dan makanan yang tidak dianjurkan seperti jeroan, alkohol, dan asinan atau acar. Tetapi hampir sebagian besar responden sebanyak 68 orang $(42.8 \%)$ tidak mengetahui jika kuning telur dapat meningkatkan tekanan darah, menurut penelitian Windyasari, (2016) menjelaskan bahwa salah satu pemicu terjadinya hipertensi adalah dengan mengkonsumsi kuning telur, karena itu bagi penderita hipertensi dianjurkan untuk mengkonsumsi putih telur nya saja.

Sebanyak 68 orang $(42.8 \%)$ masih tidak bisa membedakan makanan apa saja yang mengandung rendah lemak. Makanan yang memiliki lemak yang tinggi berisiko meningkatkan tekanan darah, karena dapat menyempitkan pembuluh darah (Legi, Rumagit, \& Ansyu, 2015). Makanan yang mengandung rendah lemak seperti susu kedelai, minyak jagung, daging tanpa kulit, putih telur, ikan, daging sapi yang kurus (Sijabat, 2016).

Sebagian besar responden sebanyak 101 orang $(63.5 \%)$ belum mengetahui jika biskuit dan makanan kering lainnya mengandung garam yang berlebih, dan tidak dianjurkan untuk penderita hipertensi. Menurut penelitian Setiyani (2018) salah satu makanan yang mengandung natrium yang berlebih adalah biskuit, crackers, keripik dan makanan kering lainnya yang asin.

\section{Sikap}

Dari hasil didapat seluruh responden 159 orang $(100 \%)$ memiliki sikap yang mendukung terhadap diet hipertensi. Sikap merupakan respon seseorang terhadap apa yang diketahuinya ( 
Gambaran pengetahuan, sikap dan perilaku tentang manajemen diet pada pasien hipertensi di Garut, Indonesia

Notoatmodjo, 2014). Karena selain pengetahuan, sikap juga dapat mempengaruhi terhadap diet hipertensi. Hasil ini sejalan dengan penelitian Mapagerang, Alimin, \& Anita (2018) bahwa sikap yang mendukung akan membentuk pribadi yang positif, dan akan menjadi sulit terpengaruh untuk melaksanakan pola makan yang tidak dianjurkan.

Dari hasil penelitian ini didapat bahwa seluruh responden sebanyak 159 orang (100\%) mempunyai sikap yang mendukung, hasil ini sejalan dengan hasil penelitian Limbong, Rumayar, \& Kandou (2018) juga menjelaskan bahwa sebanyak 52 orang $(57,8 \%)$ responden memiliki sikap yang mendukung, sikap responden tersebut merupakan sikap dari pengetahuan yang diperoleh responden kemudian bagaimana responden tersebut dapat menyikapinya. Hasil ini tidak sejalan dengan penelitian Wijayanto \& Satyabakti (2014) yang menyatakan bahwa penderita hipertensi yang berpengetahuan baik sebagian besar tidak diiringi dengan sikap yang mendukung.

Dilihat dari hasil penelitian, sebanyak 134 orang $(84,3 \%)$ memilih sangat setuju pada item pernyataan dukungan keluarga terhadap pelaksaan diet hipertensi. Menurut penelitian Tarigan et al. (2018) menjelaskan bahwa penderita hipertensi yang memiliki dukungan keluarga yang baik akan memiliki peluang 6 kali lebih besar dibandingkan yang tidak memiliki dukungan keluarga dalam melaksanakan diet hipertensi.

Hampir setengah responden memiliki sikap yang tidak mendukung yaitu 72 orang $(45.3 \%)$, yaitu pada pernyataan tentang memeriksakan diri ke pelayanan kesehatan, sebesar 28 orang $(17.6 \%)$ dan 15 orang $(9.4 \%)$ memilih tidak setuju dan kurang setuju. Itu dikarenakan saat responden merasa pusing, responden lebih memilih untuk mengkonsumsi obat. Pada item pernyataan mengatur pola makan sehari-hari, sebanyak 17 orang $(10.7 \%)$ dan 25 orang $(15.7 \%)$ memilih tidak setuju dan kurang setuju, hasil penelitian Bertalina \& Muliani (2016) mengatakan bahwa ada hubungan antara pola makan dengan hipertensi, dengan meningkatkan pola makan yang baik dapat membantu mengontrol tekanan darah.

\section{Perilaku}

Dari hasil penelitian, seluruh responden sebanyak 159 orang (100\%) memiliki perilaku yang positif untuk melakukan diet hipertensi. Faktor yang mempengaruhi perilaku adalah sikap dan pengetahuan (Notoatmodjo, 2014). Hasil ini sejalan dengan hasil penelitian heriyandi yaitu sebanyak 201 orang $(63.6 \%)$ memiliki perilaku yang positif dan 115 orang (36.4\%) memiliki perilaku yang negatif (Heriyandi et al., 2017).

Pengetahuan yang dimiliki oleh responden sebagian besar memiliki pengetahuan yang baik. Hasil ini sejalan dengan penelitian Geaney et al., (2015) bahwa pengetahuan penderita hipertensi ada hubungannya dengan kualitas pola makan sehari-hari. Sejalan juga dengan penelitian Kusumawati (2014) bahwa pengetahuan tersebut dapat mempengaruhi perilaku atau tindakan yang akan dilakukan terhadap diet hipertensi.

Hasil penelitian Anisa \& Bahri (2014) juga menjelaskan bahwa perilaku sehari-hari sangat berkaitan dengan pengetahuan, jika seseorang sudah memiliki pengetahuan tentang diet hipertensi, akan sangat memungkinkan untuk dilaksanakan dalam kehidupan sehari-hari untuk menjaga makanan yang dikonsumsi setiap hari.

Hasil dari penelitian ini, didapat sebanyak 96 orang $(60.4 \%)$ dan 18 orang $(27.7 \%)$ memilih selalu dan sering pada pernyataan mengkonsumsi sayur yang berserat. Makanan yang mengandung serat akan dengan cepat memberikan efek kenyang dan mudah dicerna oleh tubuh sehingga tidak akan menyebabkan adanya penumpukan (Nugrahaeni, 2018).

Selain mengkonsumsi sayur, responden juga memiliki perilaku yang positif pada item mengkonsumsi buah, sebanyak 95 orang $(57.9 \%)$ selalu mengkonsumsi buah, buah-buahan dapat membatasi natrium karena buah-buahan mengandung kalium (Kusumastuty et al., 2016). Pada item pernyataan mengkonsumsi makanan yang asin-asin seperti ikan asin, telor asin, pindang dan abon ada sebanyak 70 orang (44\%) jarang mengkonsumsi makanan yang mengandung garam. Dengan mengkonsumsi makanan yang rendah garam, akan membantu menurunkan tekanan darah atau mengontrol tekanan darah. (Kiha et al., 2018).

Hampir seluruh responden memiliki perilaku yang negatif yaitu 143 orang $(89.9 \%)$ tidak pernah mengganti minyak goreng nya. Minyak goreng, mentega dan margarin harus dihindari, dan sebaiknya menggantinya dengan menggunakan minyak jagung atau minyak kedelai untuk memasak (Sijabat, 2016). Selain pada tidak pernah mengganti minyak goreng, responden memiliki perilaku yang negatif pada konsumsi 
Gambaran pengetahuan, sikap dan perilaku tentang manajemen diet pada pasien hipertensi di Garut, Indonesia

biskuit/crackers, sebanyak 62 orang (39\%) masih sering mengkonsumsi biskuit/crackers karena biskuit/crackers dan makanan kering lainnya mengandung natrium atau garam juga (Bertalina \& Muliani, 2016). Hampir sebagian responden sebanyak 64 orang $(40,1.3 \%)$ masih selalu mengkonsumsi kuning telur, kuning telur tidak dianjurkan dikonsumsi oleh penderita hipertensi karena mengandung minyak jenuh atau lemak jenuh (Nita, 2018).

Dilihat dari hasil penelitian ini, sebagian besar responden memiliki perilaku yang positif sebanyak 86 orang $(54.1 \%)$, hasil ini sejalan dengan penelitian Heriyadi et al., (2017) bahwa sebanyak 201 orang $(63.6 \%)$ memiliki perilaku yang positif. Setelah membahas bagaimana perilaku pada responden di wilayah kerja Puskesmas Guntur, perilaku yang harus diubah yaitu dengan mengganti minyak goreng menggunakan minyak zaitun atau dengan tidak menggunakan minyak berulang kali, mengurangi konsumsi biskuit / crackers, dan kurangi konsumsi kuning telur. Perilaku yang harus dipertahankan yaitu dengan selalu mengkonsumsi buah, sayur, dan hindari makanan yang asin-asin.

\section{DAFTAR PUSTAKA}

Abdurrachim, R., Libri, O., Gz, S., \& Mariana, D. (2015). Hubungan Tingkat Pengetahuan Dan Konsumsi Natrium Terhadap Tekanan Darah Penderita Hipertensi Di Wilayah Kerja Puskesmas Cempaka Tahun 2015. 2(3), 103-109. http://journal.stikeshb.ac.id/index.php/jurkessia/art icle/view/13/12

Anggreani, N. (2019). Hubungan Pengetahuan Dan Sikap Lansia Dengan Riwayat Hipertensi Dalam Pengendalian Tekanan Darah Pada Lansia Di Puskesmas Sibolangit Kabupaten Deli Serdang Tahun 2019. Journal Of Chemical Information And Modeling, 53(9), 1689-1699. Https://Doi.Org/10.1017/Cbo9781107415324.004

Anisa, M., \& Bahri, T. S. (2014). Faktor-Faktor Yang Mempengaruhi Kepatuhan Diet Hipertensi. 6(1), 56-65.

http://www.jim.unsyiah.ac.id/FKep/article/view/387 6/2946
Anisah, C., \& Soleha, U. (2018). Gambaran Pola Makan Pada Penderita Hipertensi Yang Menjalani Rawat Inap Di Irna F Rsud Syarifah Ambami Rato Ebu Kabupaten Bangkalan - Madura. Journal Of Health Sciences, $7(1)$. Https://Doi.Org/10.33086/Jhs.V7i1.447

Anita, N., Ariyanti, M., \& Sarifah, S. (2014). Gambaran Tingkat Pengetahuan Lansia Tentang Diit Hipertensi Di Posyandu Lansia Sehat Mandiri Purwogondo Kartasura Sukoharjo. Jurnal Promosi Kesehatan, 2(1).

Arnett, D. K., Blumenthal, R. S., Albert, M. A., Buroker, A. B., Goldberger, Z. D., Hahn, E. J., \& Michos, E. D. (2019). 2019 ACC/AHA guideline on the primary prevention of cardiovascular disease: executive summary: a report of the American College of Cardiology/American Heart Association Task Force on Clinical Practice Guidelines. Journal of the American College of Cardiology, 74(10), 1376-1414.

Bertalina, B., \& Muliani, M. (2016). Hubungan pola makan, asupan makanan dan obesitas sentral dengan hipertensi di Puskesmas Rajabasa Indah Bandar Lampung. Jurnal Kesehatan, 7(1), 34-45.

Damayantie, N., Heryani, E., \& Muazir, M. (2018). Faktor-Faktor yang Mempengaruhi Perilaku Penatalaksanaan Hipertensi oleh Penderita di Wilayah Kerja Pskesmas Sekernan Ilir Kabupaten Muaro Jambi tahun 2018. Jurnal Ners dan Kebidanan (Journal of Ners and Midwifery), 5(3), 224-232.

Dewifianita, R. (2017). Pengaruh Pemberian Konseling Diet Dash (Dietary Approach To Stop Hypertension) Terhadap Perubahan Tekanan Darah Pada Penderita Hipertensi Peserta Prolanis Di Puskesmas Sentolo I Kabupaten Kulonprogo.

Firmawati, E. (2014). Pengaruh Blog Edukatif Tentang Hipertensi Terhadap Pengetahuan Tentang Hipertensi Dan Perilaku Diet Hipertensi Pada Pasien Hipertensi Di Wilayah Kerja 
Gambaran pengetahuan, sikap dan perilaku tentang manajemen diet pada pasien hipertensi di Garut, Indonesia

Puskesmas Wirobrajan Yogyakarta. Muhammadiyah Journal of Nursing. https://journal.umy.ac.id/index.php/ijnp/article/vie w/649/803

Geaney, F., Fitzgerald, S., Harrington, J. M., Kelly, C., Greiner, B. A., \& Perry, I. J. (2015). Nutrition Knowledge, Diet Quality And Hypertension In A Working Population. Preventive Medicine Reports, 2, 105-113. Https://Doi.Org/10.1016/J.Pmedr.2014.11.008

Heriyandi, H., Hasballah, K., \& Tahlil, T. (2018). Pengetahuan, Sikap, Dan Perilaku Diet Hipertensi Lansia Di Aceh Selatan. Jurnal IImu Keperawatan, 6(1), 57-69. http://erepository.unsyiah.ac.id/JIK/article/view/13040/12 199

Hernawan, H., \& Arifah, S. (2012). Hubungan Tingkat Pengetahuan Pasien Tentang Hipertensi dengan Sikap Kepatuhan dalam Menjalankan Diit Hipertensi di Wilayah Puskesmas Andong Kabupaten Boyolali.

Kementerian Kesehatan Republik Indonesia. (2018). Riskesdas: angka kejadian 10 penyakit di indonesia. Retrieved from https://www.litbang.kemkes.go.id/laporan-risetkesehatan-dasar-riskesdas/

Kiha, R. R., Palimbong, S., \& Kurniasari, M. D. (2018). Keefektifan Diet Rendah Garam I Pada Makanan Biasa Dan Lunak Terhadap Lama Kesembuhan Pasien Hipertensi. Jurnal Keperawatan Muhammadiyah. Https://Doi.Org/10.30651/Jkm.V3i1.1574

Kusumastuty, I., Widyani, D., \& Wahyuni, E. S. (2016). Asupan Protein Dan Kalium Berhubungan Dengan Penurunan Tekanan Darah Pasien Hipertensi Rawat Jalan (Protein And Potassium Intake Related To Decreased Blood Pressure In Outclinic Hypertensive Patients). Indonesian Journal of Human Nutrition, 3(1), 19-28.. Https://Doi.Org/10.21776/Ub.ljhn.2016.003.01.3
Kusumawaty, J., Hidayat, N., \& Ginanjar, E. (2016). Hubungan Jenis Kelamin Dengan Intensitas Hipertensi Pada Lansia Di Wilayah Factors Related Events Sex With Hypertension In Elderly Work Area Health District Lakbok Ciamis. 16(2), 46-51.

https://journal.umy.ac.id/index.php/mm/article/vie w/4450/3514

Legi, N. N., Rumagit, F. A., \& Ansyu, E. Y. (2015). Asupan Lemak Dan Natrium Pada Penderita Hipertensi Di Puskesmas Paceda Kecamatan Madidir Kota Bitung. 10(1). https://ejurnal.poltekkesmanado.ac.id/index.php/infokes/article/view/272/2 42

Limbong, E. (2020). Hubungan pengetahuan keluarga dengan pemberian diet pada penderita hipertensi di puskesmas pancur batu di tahun 2019.

Limbong, V. A., Rumayar, A., \& Kandou, G. D. (2018). Hubungan Pengetahuan Dan Sikap Dengan Kejadian Hipertensi Di Wilayah Kerja Puskesmas Tateli Kabupaten Minahasa. Jurnal Kesmas, 7.

Mappagerang, R., Alimin, M., \& Anita, A. (2018). Hubungan Pengetahuan Dan Sikap Pada Penderita Hipertensi Dengan Kontrol Diet Rendah Garam. JIKP Jurnal IImiah Kesehatan Pencerah, 7(1), 37-44.

Nita, S. (2018). Ketidakpatuhan Pola Makan Pada Pasien Hipertensi Di Kota Malang.

Nugrahaeni, D. K. (2018). Umur Lebih Dari 45 Tahun Dan Rendahnya Konsumsi Serat Beresiko Terkena Hipertensi. 1-9.

Nuridayanti, A. (2016). Pengaruh Edukasi Diet Dan Terapi Obat Terhadap Pengetahuan, Perilaku Diet Dan Kepatuhan Minum Obat Penderita Hipertensi Di Pos Pembinaan Terpadu Kelurahan Mojoroto Kota Kediri Jawa Timur Tesis. 62-98. 
Gambaran pengetahuan, sikap dan perilaku tentang manajemen diet pada pasien hipertensi di Garut, Indonesia

Proboningsih, J., \& Almahmudah, M. (2019). Gambaran Kepatuhan Diet Dan Minum Obat Pada Pasien Hipertensi Di Wilayah Kerja Puskesmas Pacar Keling Surabaya. In Prosiding Seminar Nasional Kesehatan Poltekkes Kemenkes Surabaya (Vol. 1, No. 1, pp. 6-10).

Runtukahu, R. F., Rompas, S., \& Pondaag, L. (2015). Analisis Faktor-Faktor Yang Berhubungan Dengan Kepatuhan Melaksanakan Diet Pada Penderita Hipertensi Di Wilayah Kerja Puskesmas Wolaang Kecamatan Langowan Timur. Jurnal Keperawatan Unsrat, 3(2).

Setiyani, E. (2018). Perbedaan Asupan Natrium (Na), Kalium (K) Sebelum Dan Sesudah Edukasi Pada Pasien Hipertensi Rawat Jalan Di Puskesmas Wonokerto li Kabupaten Pekalongan Jawa Tengah. 83.

Sijabat, S. N. R. P. (2016). Gambaran Pengetahuan Dan Sikap Pasien Hipertensi Tentang Diet Hipertensi Di Puskesmas Andalas Padang Tahun 2015.

Syamsudin, D. (2011). Buku Ajar Farmakologi Kardiovaskuler Dan Renal. Jakarta: Salemba Medika.

Tarigan, A. R., Lubis, Z., \& Syarifah, S. (2018). Pengaruh Pengetahuan, Sikap Dan Dukungan Keluarga Terhadap Diet Hipertensi Di Desa Hulu Kecamatan Pancur Batu Tahun 2016. Jurnal Kesehatan.
Wandi, W., \& Amin, I. (2017). Deteksi Dini Hipertensi dan Pertolongan Pertama pada Penderita Stroke di Desa Amadanom Kecamatan Dampit Kabupaten Malang. Jurnal IDAMAN (Induk Pemberdayaan Masyarakat Pedesaan), 1(1), 2732

Wawan, A., \& Dewi, M. (2010). Teori dan pengukuran pengetahuan, sikap dan perilaku manusia. Yogyakarta: Nuha Medika, 11-18.

Wijayanto, W., \& Satyabakti, P. (2014). Hubungan Tingkat Pengetahuan Komplikasi Hipertensi Dengan Keteraturan Kunjungan Penderita Hipertensi Usia 45 Tahun Ke Atas. Jurnal Berkala Epidemiologi, 2(1), 24-33.

Windyasari, R. S. (2016).Hubungan antara Konsumsi Makanan dengan Kejadian Hipertensi pada PRA Lansia di Wilayah Kerja Uptd Puskesmas Kampung Bangka Kecamatan Pontianak Tenggara (Doctoral dissertation, Tanjungpura University

Reny, A. Y. (2014). Buku Ajar Asuhan Keperawatan Klien Dengan Gangguann Sistem Kasdiovaskuler.

Zaini, A., Ratnawati, L., \& Ririanty, M. (2015). Hubungan Antara Pengetahuan, Sikap, Dan Tindakan Keluarga Tentang Diet Rendah Garam Dengan Konsumsi Lansia Hipertensi: Studi Di Wilayah Kerja Puskesmas Pakusari Kabupaten Jember. Universitas Jember. 